\title{
Starting from the Case Concerning the Detention of Three Ukrainian Vessels and Deriving Suggestions and Examining the Definition of Military Activities as Well as Three Possible Consequences
}

\author{
Ziyun $\mathrm{Li}^{1}$ \\ ${ }^{1}$ Tianjin Yinghua International School
'Corresponding author. Email:1637020974@qq.com \\ ABSTRACT \\ This article explores the definition of military activity arising from the case concerning the detention of three Ukrainian \\ vessels. Vague definition not only causes problems of interpretation and the consequences of judicial legislation, but \\ also if the jurisdiction of the court is exceeded, judicial expansion may occur. Compared with the South China Sea \\ arbitration, different interpretations of military activities may lead to judicial divisions. This article will also study the \\ pros and cons of each of the three.
}

Keywords: International Law of Sea, Judaical fragmentation Judicial expansion , Judicial Lawmaking, military activity.

\section{BACKGROUND OF THE CASE CONCERNING THE DETENTION OF THREE UKRAINIAN VESSELS}

\subsection{Overview of the Kerch Strait Incident}

The Arbitral Tribunal held a procedural hearing on 21th November 2019 referring to the dispute concerning the detention of three Ukrainian vessels at the premises of the Permanent Court of Arbitration. Under Procedural Order NO.2, Russian Federation mentioned the applicability of military activity which would exclude jurisdiction of Tribunal. Then Ukraine offered its submission and responded that 'the Arbitral Tribunal

would have to consider "the same facts and evidence" upon which the merits of Ukraine's claims turn'. This case was parallel with the detention of vessel cases(Ukraine v. Russia). The purpose of Ukraine may be to counter against Russia in the international litigations, with a view to the resolution of Crimean sovereign dispute.

The incident started when Ukraine intended to send three vessels, the former Ukrainian Navy artillery boats Berdyansk and Nikopol, and the Ukrainian Navy tugboat Yani Kapu, to the port of Berdyansk in the Sea of Azov.
Before entering the Kerch Strait on 25th November 2018, through which the vessels needed to pass to reach their destination, the Russian Coast Guard launched a radio communication to notify the Ukrainian ships of the closure of the Kerch Strait. The three Ukrainian ships were forcibly intercepted by ships of the Russian Federation Coast Guard. After being blocked, the Ukrainian vessels were about to turn around and leave the strait, but were pursued by the Russian Coast Guard vessels. The Berdyansk was fired upon and damaged by a Russian vessel. The shooting also injured three Ukrainian crew members. A total of 24 Ukrainian vessels, including their crew, were captured by the Russian Federation. Subsequently, from November 26 to 27, in accordance with Article 91 of the Criminal Procedure Law of the Russian Federation, 24 military personnel were formally arrested on suspicion of the crime of illegally crossing the border of the Russian Federation.[1] When Ukraine requested the arbitration tribunal to take provisional measures, Ukraine stated that the Russian Federation had violated the rights of their crew members and their vessels, causing "a grave threat of irreparable harm to the rights of the flag State". In addition, Ukraine claimed that Russia's actions challenged Ukraine's dignity and sovereignty.[2] 


\subsection{The context of the Kerch Strait Incident, the Crimean war, and its impact on this incident}

Under an agreement on the utility of the Sea of Azov and the Kerch Strait signed in 2003 between the Russian Federation and Ukraine, merchant ships and warships from these two countries have the right of free navigation, while other countries intending to transit through the strait need to obtain the consent of the two countries. In 2015, Russia began to build a bridge across the Kerch Strait, preventing and delaying the passage of any ships, including Ukrainian ships.[3] Russia's blockade of the strait was considered as a first step in overturning the 2003 agreement. It is worth noting that at the time of the Kerch Strait Incident in 2018, the 2003 agreement was still valid between the signatories; thus, the actions taken by the Russian Federation in this case were described as “purely Russian military aggression".[4] The Crimean War was a turning point in the transformation of the relationship between the two countries. Both claimed sovereignty over the Crimea, while the sovereignty of Ukraine was, in effect, taken away by the Russian Federation after it had built the bridge. Russia's violation

of the 2003 agreement by blocking the Kerch Strait may be one of the key factors in determining whether Russia's

actions in the Kerch Strait Incident fall within the scope of military activities. Most judges believe that the verdict should take into account the relevant facts and events before the Kerch Strait Incident, such as Russia's deliberate blockade of the Kerch Strait without Ukraine's consent.

\subsection{Judicial proceedings of the incident}

Both states are parties to the Convention, and had chosen an arbitral tribunal for dispute settlement in a

ccordance with Article 287 as the "principal" or "basic"

means.[5]At the same time, Ukraine claimed that "a

grave threat of irreparable harm to the rights of the flag State" would occur while awaiting the result, and thus the arbitral tribunal should stipulate provisional measures.[6] However, the prescription of provisional measures are only valid when "provisions invoked by the Applicant

prima facie appear to afford a basis on which the jurisdiction of the Annex VII arbitral tribunal could be founded, but need not definitively satisfy itself that the Annex VII arbitral tribunal has jurisdiction over the dispute submitted to it".[7] In order to set up the tribunal, the requirement that "a dispute concern the interpretation or application of this Convention" should be satisfied prima facie. As Ukraine claimed that Russia had breached its obligations under Articles 32, 58, 95 and 96 of the Convention, in the view of the Ukraine, there was a dispute concerning the interpretation and application of UNCLOS. The tribunal held the view that the arrest of the Ukrainian vessels and the commencement of criminal proceedings against the Ukrainian servicemen both proved that the Russian Federation had a different interpretation of Articles 32, 58, 95 and 96 of the Convention, which fulfilled the prima facie requirement for setting up the arbitral tribunal.

However, the Russian Federation rejected all the aforementioned actions claimed by Ukraine by stating that the incident was within the scope of the exemption for military activity, which excludes the jurisdiction from Article 288 of the arbitral tribunal pursuant to Article 298. As 28 states had already excluded the jurisdiction over military activities, including Russia and Ukraine, Russia denied the establishment of an arbitral tribunal. The dispute over this question culminated in the tribunal's refusal of the alleged military exception requested by Russia.

\section{THE JURISPRUDENCE OF THE CASE CONCERNING THE IDENTIFICATION OF MILITARY ACTIVITIES AND LAW- ENFORCEMENT ACTIVITIES}

\subsection{The majority opinion}

Considering Article 298, 1(b) with respect to Russia's claim to exclude jurisdiction on the Kerch Strait Incident:

(b) disputes concerning military activities, including military activities by government vessels and aircraft engaged in non-commercial service, and disputes concerning law enforcement activities in regard to the exercise of sovereign rights or jurisdiction excluded from the jurisdiction of a court or tribunal under article 297, paragraph 2 or $3 \ldots$

The paramount issue is to decide whether the conflict involves military activities. As the drafters of the Convention did not define the term "military activity", the arbitral tribunal bears the responsibility of interpreting the term.

To reach a conclusion, the arbitral tribunal considered three factors. First, the application of naval vessels seems to be one of the factors of concern for the two countries, as warships represent national sovereignty. According to the arbitration tribunal, the distinction between the two types of ships had become blurred, so it was not enough to accuse either state of military activities based on the type of vessel. [8]Second, from the perspective of Ukraine, the question was whether they had been violated due to their crews and ships being detained and their crews facing criminal proceedings, according to Articles 32, 58, 95 and 96 of the Convention. The arbitration tribunal was clear that the root cause of this incident lies in the misunderstanding of how the Convention applied 
to the passage of the Kerch Strait. The tribunal pointed out that the passage regime that applies to all ships does not apply in the same way to military activities.[9]Finally, firing upon the Ukrainian ships was the turning point of the incident, and the background of the firing was an important factor to be considered. It was at the moment of the chase that the Russian ships opened fire and damaged the Ukrainian vessels as a result, so they were not "arrayed in opposition to one another.[10] Therefore,

shooting occurred in the context of law-enforcement activities, not military.

Overall, the majority of the tribunal rendered that Article 298, 1(b) did not apply in this case. In other words, Russia failed to claim that its actions in the incident were military activities.

\subsection{The separate opinions}

Judge Gao, Judge Kolodkin and Judge Kittchiaisaree offered separate opinions concerning the applicability of Article 298 1(b).

In the response to the Order that "it is not uncommon

for States today to employ naval and law enforcement vessels collaboratively for diverse maritime tasks", Judge Kolodkin stated that the shipping of warships is at least superficially a military activity.[11] It is well accepted that warships enjoy the right of immunity and freedom of navigation; from this perspective the distinction between warships and other types of vessels is not blurred. Comparing the majority judges 'opinions in the Order, "it

is not uncommon today for States to employ the two types of vessels collaboratively for diverse maritime tasks".[12] In addition, Kololdkin specified that when a country is navigating a warship under the assumption that it enjoys the right of immunity, the nature of such navigation should be presumed to be military,[13] because the reason for the exception of military activities is to offset the immunity enjoyed by the flag state. With the further support of the "ARA Libertad" case which Judge Gao

referred, warships have been used to symbolize the sovereignty of the flag state.[14] The navigation of the Ukrainian naval vessels should have been characterized as military activity.

With regard to the sequence of the incident, all three judges agreed that the incident involved both military and law-enforcement activities at various points. In particular, the jurisprudence of "ARA Libertad" has demonstrated "the escalation of circumstances" as a method, through which the tribunal can identify firing activities as the focal point of escalating military activities. According to Judge Kolodkin's elaboration on the steps involved in this incident, the Russian Federation's detection and warning of Ukraine's vessels, followed by the involvement of the Russian Federation's naval and air force, were clearly military activities. The blocking of the Kerch Strait despite the terms of the 2003 agreement in 2003, was exacerbated when, after obstructing the passage of the Ukrainian vessels for eight hours, followed by the Ukrainian vessels deliberately ignoring the radio communications from the Russian Coast Guard, aggravated the situation to the point of military activities. Because Russia alleged that the Ukrainian vessels had violated section 3 of Article 322 of the Criminal Code of the Russian Federation, the subsequent detention of vessels and crew members could be defined as a lawenforcement activity; however, this must be considered within the broader context of the incident as a whole, which includes both military and law-enforcement activities.

\subsection{Concluding remarks}

Several variations on determining whether the incident is covered by Article 298 1(b), the military activity exception, are presented.

The intense conflicts between the majority and minority of the judges can be summarize as constituting three aspects. First, they differed in the weight they gave the fact that the Russian Federation arrested Ukrainian vessels and crew. The minority asserted that the subsequent detention after pursuing and firing on the vessels was only a relevant factor, not the predominant one, when deciding the applicability of the military exception, and that under the Order, the single action taken by the Russian Federation had the nature of a lawenforcement activity.

Second, the Order is generally interpreted to mean that the participation of warships is a marginal aspect of the characterization of disputes. In contrast, some judges claimed that the use of warships symbolized sovereignty and demonstrated at least the appearance of a military activity.

Finally, the judges' concerns differed. The Order focuses on the context of Russia's use of force, which was the moment that Ukraine ships ignored the radio communications, and the majority of judges alleged that this context proved that the incident was in the nature of a law-enforcement activity. The analysis is not clear, as they provided little explanation for how pursuit and firing upon the vessels contributed to the nature of a lawenforcement activity. In contrast, the minority of judges identified the stages of the incident step by step and focused particularly on the moment at which they asserted that the incident escalated to a military activity.

Therefore, from the above-mentioned comparison between the minority and the Order, a question remains, that is, when the reasonings of both are reasonable, judges who face similar problems in the future should choose which one to believe. In addition to leaving 
concerns for judges facing similar cases, the disputed country and third parties may also argue about why the judges in the previous case involving military activities have different conclusions from this case. In the future, there would be a debate on whether to adopt the minority opinions or the majority opinions when both are logical and reasonable. Therefore, it may potentially create the problem of judicial fragmentation.

\section{COMMENTS ON THE COURT'S}

\section{APPROACH IN THE IDENTIFICATION OF MILITARY OR LAW-ENFORCEMENT ACTIVITIES}

\subsection{The functions of Article 298 involving the military exemption}

In the process of globalization and the need for world peace, it is important that as many states as possible accept the same system of legislation. Several factors have come into play for states to accept and sign the United Nations Convention on the Law of the Sea.

First, ambiguity is one of the ways for the global community to reach a consensus on the interpretation of UNCLOS.[15] Before a state would accept such a treaty, which would require them to relinquish some of their rights, they would need to weigh the rights they would lose against what they would gain. A too-strict treaty would lead some states conclude that their rights would be infringed to an unacceptable degree, while a toolenient treaty would not constrain states' actions sufficiently to the treaty's aims. Moreover, a too-vague treaty would leave room for each country to make different interpretations during disputes. In this case, countries would feel that they themselves control and reserve their rights, rather than being deprived of these rights by a treaty.[16] Therefore the objective in determining the specific limitation on states' behaviors is to set ambitious terms without explaining their exact meaning.

Second, coastal states have expressed concerns that the right of immunity of warships and naval vessels according to Articles 32, 58, 95 and 96 of the Convention could be abused by states flying their flags. Therefore the introduction of the military exemption in Article 298 of the Convention acts as a counter-balance to protect the sovereignty of costal states.[17]

Based on these two factors, the courts should interpret the definition of military activities based on the nature of a specific incident, as the interpretation of sovereignty could be explained variously from state to state. Also, Article 298 is targeted directly at costal states, which, in the case of the Kerch Strait Incident, is the Russian Federation. Hence, when the Russian Federation alleged that the Ukraine shipping vessels were a "secret invader", this indicated that the Russian Federation thought that its sovereignty had been threatened.

However, with the support of Article 19 of the UNCLOS:

2. Passage of a foreign ship shall be considered to be prejudicial to the peace, good order or security of the coastal State if in the territorial sea it engages in any of the following activities:

any threat or use of force against the sovereignty, territorial integrity or political independence of the coastal State, or in any other manner in violation of the principles of international law embodied in the Charter of the United Nations;

(b)any exercise or practice with weapons of any kind;

(f) the launching, landing or taking on board of any military device....

The Convention's text clearly shows that warships cannot engage in military activities against costal states' sovereignty.[18] The only actions related to the Kerch Strait Incident are described in Article 19 2(e) and (f), where Russian Coast Guard detained Ukrainian crew members. However, the detention was instigated by the Russian Federation - in other words, the coastal state not the Ukrainian vessels, which turned round without using any force. Therefore, at least in relation to detention, Ukraine was not involved in military activities.

\subsection{The proposed solutions to the mixed disputes that involve both military and law enforcement activities}

In the view of the tribunal, military and lawenforcement activities are mutually exclusive.[19] In contrast, in Kittchiaisaree's separate opinions, military activities can evolve from law-enforcement activities; hence they are in an intertwined relationship.[20]

As discussed in Section 2.2, the incident was divided into stages that involve both military and lawenforcement activities. The warning stage is wellaccepted as a law-enforcement activity, as in Judge Kittchiaisaree's separate opinion: The use of force in the present case was also in the context of law- enforcement operations at sea alluded to in M/V "SAIGA" (No. 2):

The normal practice used to stop a ship at sea is first to give an auditory or visual signal to stop, using internationally recognized signals. Where this does not succeed, a variety of actions may be taken, including the firing of shots across the bows of the ship. It is only after the appropriate actions fail that the pursuing vessel may, as a last resort, use force. Even then, appropriate warning must be issued to the ship and all efforts should be made to ensure that life is not endangered (S.S. "I'm Alone" case (Canada/United States, 1935), U.N.R.I.A.A., Vol. III, p. 1609; The Red Crusader case (Commission of 
Enquiry, Denmark - United Kingdom, 1962), I.L.R, Vol. 35 , p. 485)[21]

In the above context, "using internationally recognized signals" is the fundamental requirement for coastal countries to carry out military activities. Each country should first follow the minimum standard steps in a conflict. When the signal is used without feedback from the flag state, the specific event may be considered as a military activity, rather than a law-enforcement activity. The Convention determines that lawenforcement activities are under the jurisdiction of the International Courts and tribunals because such acts only involve infringement of the sovereignty of one party, while military activities usually involve infringement of the sovereignty of at least two parties. It is the involvement of the sovereignty of the two countries that lead to the exclusion of the jurisdiction of the International Courts and tribunals. In this case, the pursuit phase only involved an infringement of Russian sovereignty, known as a "secret invasion", while the phase of shooting at the ship and crew members involved infringement of Ukrainian sovereignty. Also, lawenforcement operations should involve a hierarchical relationship between the enforcing authority and the object of the enforcement actions.[22] In other words, military activities require the rights of two countries to be at the same level. Therefore, due to the imbalance of power - that is, sovereignty, the courts and tribunals would exercise jurisdiction. In the Kerch Strait Incident, the sovereignties of the two countries were infringed at the same time; thus it was recognized as a military exception.

Given that military and law-enforcement activities are not mutually exclusive, which one in particular should be taken for reaching a verdict is questionable. Until the initiation of activities that are clearly military, all the alleged law-enforcement activities foreshadow military operations. The warning by radio communications was similar in nature to the violation of the 2003 agreement and the Crimean War, as all of them acted as a base for an escalation into military activities. Therefore, rather than saying the incident involved both military and law-enforcement activities, it was in nature a military activity that was generated from actions or preceding events that could be treated as lawenforcement operations. From the perspective of the Kerch Strait Incident, when military and lawenforcement activities are combined, judges can consider whether the cause of the incident is military activity, and if it is, whether the behavior before the military operation (such as shooting) is the fuse for the development of military activity.

Therefore, based on the above reasons, each case would be complex, involving multiple stages and complex historical background. Hence, I agree with the opinion of the minority judges to divide the case into stages. There are some arguments that justify my difference from the Order when concerning the term military activity. Firstly, it is reasonable for judges to conclude that the use of navel vessels is blurred nowadays as it is a common situation seen by judges, but as long as the UNCLOs stipulated that 'military activities by government vessels and aircraft engaged in noncommercial service', it is not appropriate to interpret that the use of navel vessels is not a military one. Secondly, the Russian Federation's conviction against Ukraine navel vessels are deemed as law enforcement activity by the majority judges, but as there is not hierarchical difference between Russian Federation. Since military exception is a counterbalance of innocence of passage enjoyed by passage of foreign ships and it offers a same level of statues for costal states as foreign vessels, thus military activity differs from law enforcement activity on the ground that two state parties are on the same hierarchical level. Moreover, judges may also consider the application of Article 19. Article 19 not only provides foreign vessels a warn about which actions are not allowed, but also provides a reference for costal states the lowest limit that they can act against those foreign vessels.[23] Warnings, such as sending communication signals, may symbolize the beginning of prejudicial actions that undermine the sovereignty of coastal states. In this case, the Ukrainian ship only turned around and were about to leave and were suspected of infringing on its sovereignty by the Russian Federation. It is difficult to objectively judge whether Ukrainian ships violate the sovereignty of coastal countries and whether they implemented prejudicial actions.

\section{IMPLICATION OF THE CASE CONCERNING THE DETENTION OF THE THREE UKRAINE VESSELS}

This section will explain how two related cases can create three intertwined effects. It first outlines the purpose and conflicts of the South China Sea arbitration case, which was used to define military activities in a different way in comparison with the case concerning the detention of three Ukraine vessels. Then, next section would examine some consequences of using different interpretations and methodologies regarding the same term in the Convention.

\subsection{A different interpretation on military activity}

\subsubsection{Overview of South China Sea Arbitration}

This case involves several claims on sovereignty over the South China Sea, including those of China,Taiwan, and the ASEAN states of Brunei, Malaysia, the Philippines, and Vietnam. One specific issue related to military activity in the South China Sea was China's occupation of Mischief Reef, which led to the Philippines' request for arbitration against China in January 2013 to 
decide whether the dispute fell within the scope of a military exception under 298 1(b). One aspect considered by judges before the arbitral tribunal reached its conclusion is worth noting: while the arbitral tribunal took into account China's repeated statements that its installations and island construction were intended to fulfill civilian purposes and their construction on Nansha Islands was not influencing any states, the judges concluded that when deciding an incidence in relation to a military exception, it should consider "whether the dispute itself concerns military activities, rather than whether a party has employed its military in some manner in relation to the dispute".

\subsubsection{Comparisons between the two cases}

When examining the verdicts of the two cases on the question of military exception under Article 298, 1(b), it is worthwhile to look at where they are similar and where they differ.

In the verdict on the detention of the three Ukrainian ships, the arbitration tribunal mentioned that the subjective characterization of military activities by one party cannot be regarded as a military act, as it is "subjective" and only a "relevant factor". [24]Although the rationale behind this paragraph was not explicitly explained in the Order, the ruling on the dispute in the South China Sea pointed out that the political, legal and other consequences associated with one party would go far beyond the scope of Article 298, even beyond "the interpretation and application of UNCLOS" .[25]

In both cases, tribunals mentioned that the characteristics of one party's military activity (Russia and China, respectively) should be considered in order to give a conclusion on whether the military-activity exception applies. In the South China Sea dispute, even if the arbitral tribunal had admitted that it should not base its decision solely on the characteristics of one party's claims, the tribunal accepted China's assertion that its activities were of a civilian nature, and thus beyond the scope of military activities, and "accept[ed] the position that China has repeatedly confirmed that civilian use is the main (if not the only) motive for the dramatic changes in hoax reefs".[26] The commonality between the two cases is that both courts denied the importance of unilateral characterization. In the South China Sea dispute, the court held that China not only classified its behavior as a non-military operation, but also explicitly stated that the construction of islands was for civilian purpose. In the case concerning the detention of three Ukrainian vessels, the arbitration tribunal adopted the same approach as to the South China Sea dispute; that is, it could not rely solely on Russia's assertion that its actions were military in nature, but Russia had not further clarified the characteristics of its actions. Therefore, the methodology adopted by the two tribunals was the same: that a country's unilateral description of its actions is subjective and unreliable, and only after these actions are considered and accepted by the judges can it be determined whether they are military in nature. The only difference is the facts and explanations of actions in the two cases. Specifically, China further concretized its actions, not only describing its actions as non-military actions, but also saying that these actions were used by civilians,[27] while Russia only denied that its actions were military, giving no further explanation.

The judges in the disputes also mentioned that disputes should stem from military activities and not from other starting points involving military actions; in other words, military activity should be the "root" of a dispute. Therefore, the key is to distinguish between "involvement" and "root". In adjudicating the South China Sea dispute, the arbitral tribunal pointed out that the deciding factor was "whether the dispute itself concerns military activities, rather than whether a party has employed its military in some manner in relation to the dispute".[28] Military activities should be the starting point and source of a dispute, not the second or third step in the dispute (if the incident involves multiple stages). Although the majority of judges in the Order in the case concerning the detention of three Ukrainian vessels did not consider this point, Judges Gao and Kolodkin both concluded in their separate opinions by asserting that there were multiple stages in this case, and that a specific stage involved the escalation into a military activity. The case started when Russia sent radio communications to the Ukrainian ships, and then the Ukrainian vessels turned back and left. Neither of these acts was a military activity. The two judges believed that even if only one of the stages had been military activity, the whole case should be counted in the military activity exception. Therefore, it can be seen that the minority believed that no matter which stage of the occurrence involves military activities, such incidents should be classified as military activities.

\subsection{Judicial law-making}

In both cases, the judges expressed their own understanding and reasoning on the term "military activity". A comparison of the two rulings first raises the question of the nature of judicial law-making.

Judicial law-making originated from the fact that the language of the Law of the Sea Convention is flexible and ambiguous, which allows judges to interpret and apply the rules to a variety of emerging situations. Although there is specification that "the primary function of the ICJ is not law-making but the application of law in the settlement of disputes", the ICJ does play a major lawmaking role as a subsidiary, or indirect, consequence of its role in the settlement of disputes.[29] It is indeed important for judges to fill the gaps in the definition of terms such as "military activities", but if different judges interpret the same legal norms differently, this may cause 
confusion for judges or third parties. Different applications may set multiple parameters for the legality of certain actions.

A common concern of the judicial law-making function is that it will create precedents that will have an effect on third parties and judges in similar cases. Thirdparty countries may struggle with which explanation to follow when encountering similar situations in the future. In the Kerch Strait Incident, even though the Russian Federation opened fire, the military-activity exception was invalid. In the tribunal of the Philippines v. China, the judge believed that the fact that the parties were "arrayed in opposition to one another" was sufficient to characterize the incident as a military activity.[30] At the same time, judicial law-making is closely related to international customary law. The development of international customary law requires sufficient state practice and opinio juris. In this case, state practice should be related to military activities, including either "firing [upon]" or "arrayed in opposition to one another". If international customary law is formed through continuous state practice, it would contradict the purpose of the international legal system, which is aimed at avoiding the use of force.

However, the fundamental root of judicial lawmaking is judicial fragmentation. In the case concerning the detention of the three Ukraine vessels, the judges wrote down their understanding of the term "military activity", but this interpretation differed from that of other cases. Therefore, it can be said that judges with professional status are more likely to make judgements different from those of the International Court of Justice. The decisions made by the International Court of Justice are based more on general international law, while professional courts or arbitral tribunals may pay more attention to professional knowledge. The next section further examines judicial fragmentation and its possible consequences.

\subsection{Judicial fragmentation}

The International Tribunal for the Law of the Sea (ITLOS) was founded in October 1996 and was constituted of 21 judges. It is questionable whether the establishment of ITLOS dispersed the judicial function of International Court of Justice (ICJ), which is the key organ of international judicial settlement, and if so, whether that would cause states to lose confidence in the ICJ. Although the negotiation that gave rise to UNCLOS involved many countries, some Third World countries were unsatisfied and felt that their views and opinions were given less weight than those of developed countries. With cases such as "the South-West Africa cases" '(1962 and 1966) and the "Northern Cameroons case"[31] further exacerbating conflicts in Africa, the Third World countries began to lose confidence in the ICJ and gradually supported the establishment of ITLOS.[32]
Although the proliferation of specialized international institutions stems from the needs of some developing countries, the increase in specialized fields has led some international lawyers and judges to pay more attention to a specific area of international law, such as the law of the sea or human rights law, while ignoring the application of general international law.[33] Furthermore, due to the existence of different treaties concerning different and special matters, the judicial organs created by those treaties pay less attention to the "connection, legal relationship between general international law and the newly-established mechanism".[34] The divergence concerns many scholars and judges, who believe that the international law of the sea and human rights law should be a further refinement and development of general international law, rather than a new and separate legal system that has the potential to run counter to the general international law. The international law mechanism is a common heritage of the nineteenth the twentieth centuries, and it should be refined and at least have legal relationships with the specific international law to fit the legal system of the modern world.[35]The development of new laws does not mean that they have nothing to do with the existing general international law, but are instead based on the existing law to ultimately form a more comprehensive, detailed and persuasive law. This point should be considered in the establishment of new institutions.

As long as newly established institutions pay attention to and avoid these problems as much as possible, the proliferation of institutions may be beneficial, because in cases such as military activity disputes, the existence of more institutions, including the ICJ and the specialized courts and tribunals means that they can correct and complement each other, and innovate in the practice of law.[36]

As judicial fragmentation is more likely to lead to judicial law-making, when judges make different interpretations of Article 298 of the Law of the Sea Convention, the problem of judicial expansion may arise.

\subsection{Judicial expansion}

Article 288 of UNCLOS defines the scope of its jurisdiction:"the court or tribunal referred to in Article 287 shall have jurisdiction over any dispute concerning the interpretation or application of this Convention". While concerning the sovereignty of countries, Article 298 of UNCLOS excludes certain aspects of countries' activities from the jurisdiction defined by Article 288. For instance, in the case concerning the detention of the three Ukraine vessels, the Russian Federation claimed that its actions fell within the scope of military activity, in accordance with Article 298 1(b), and thus asserted that no tribunals and courts referred to in Article 287 had jurisdiction over it. 
Judicial expansion is related to the scope of subjectmatter jurisdiction. According to Article 288,1, the requirement "concerning the interpretation or application of this Convention" is relatively vague, because the incident may involve multiple conflicts, one of which may comply with the provisions of the "concerning Interpretation or Application of this Convention", while the other does not. In this case, if the Russian Federation's opening fire on the Ukrainian ships was deemed to be a military activity, the tribunal would have no jurisdiction in accordance with Article 298 1(b), while the passage in the Kerch Strait was considered by the majority of judges in the Order as "concerning the interpretation or application of this Convention". These two conflicts have led to the question of whether the entire case should be excluded from the jurisdiction of the tribunal If the court has jurisdiction due to facts other than the Russian Federation's opening fire upon the Ukrainian vessels, such as the passage of the Kerch Strait, this is an example of judicial expansion. If the arbitration tribunal can only deal with a part of the dispute, it should exclude the conduct specified in Article 298, filter out which conduct meets the jurisdiction of Article 287, and then only deal with the conduct within the scope of Article 287; in this case, the passage of the Kerch Strait. The arbitral tribunal can then only have jurisdiction over the part of dispute "concerning the interpretation or application of this Convention". Since judicial expansion means that courts or tribunals have jurisdiction over the dispute that should be excluded under Article 298, by distinguishing various types of conduct in one particular case and characterizing each of them, judicial expansion would be avoided as much as possible while protecting the sovereignty of state parties.

From the South China Sea arbitration case, the standard for military activities is "arrayed opposed to each other". If the case concerning the detention of the three Ukrainian vessels applies the same criteria as above, it shall be excluded from the jurisdiction under Article 298.

\subsection{Summary of the above consequences}

Even though the two cases seem to adopt similar methodology, some differences still remain that could cause confusion for member states as well as third parties. With the creation of judicial fragmentation and problems owing to judicial law-making by each tribunal, there can be several possible consequences.

First, those who would like to join the Convention and UNCLOS would be delayed in their decisions due to their confusion about which verdict they should follow. Even though a verdict is only binding on the two parties involved in a case, other states would treat it as a reference for a particular action; in this case, military activity. One state would withdraw their decision on joining the Convention if they considered that the deviation or different conclusions would potentially infringe on their rights and sovereignty. Second, the different conclusions regarding the interpretation of a single term in the Convention or a treaty are deemed as uncertainty for International law and courts, which would cause states to lose faith in the international courts and tribunals. Finally, if judges found that uncertainty and flexibility caused problems such as those discussed above, they may limit themselves to follow the precedent of existing cases as closely as possible. Though this would avoid the risks of uncertainty and the resulting loss of faith by member countries, the cost would be that the evolving interpretation of international law would cease. The decision chosen between conflicting objectives evolution and states' willingness to trust - is a longstanding question that remains to be solved.

\section{CONCLUSION}

The case of the detention of the three Ukrainian vessels has sparked discussions on the concept and thresholds of military activities. This paper compares the Ukraine v. Russia case and South China Sea Arbitration case, and further illustrates how different interpretations of the same term can lead to judicial fragmentation. This is the price of UNCLOS's drafters' use of ambiguous clauses to encourage more countries to join the treaty.

Due to the lack of a hierarchy of international legal institutions, the uncertainty and flexibility brought about by judicial fragmentation have caused confusion among judges and third parties participating in the treaty. The establishment of specialized courts that meet the requirements of Third World countries would allow judges to make decisions based more on their professional fields than on general international law. International law is still in the development stage. Although the common heritage of the nineteenth and twentieth centuries (general international law) should be protected and upheld, there are still gaps in existing laws, and the creation of international customary law is needed. Unlike the ICJ, professional courts and tribunals pay more attention to their professional fields; thus they take a professional perspective when considering the defects and gaps in general international law. Within the framework of general international law, specialized courts and tribunals can cooperate with the ICJ, and the legal system of international law would be more complete and comprehensive.

The lower the standard, the more likely the courts would interfere with conflicts. Countries fear that their sovereignty would be affected by judicial expansion. Hence I think that if a case is complicated and consists of multiple events, tribunals and courts should only intervene in the matters within Article 287, as this will protect the national sovereignty addressed by Article 298 . However, more problems stem from the interpretation of Article 298, such as the term "military activity". 
Therefore, judicial expansion, judicial fragmentation, and judicial law-making are interrelated. With the development of specialized courts and tribunals and the deficiencies of the Convention and other treaties, the legislative function is inevitable. Therefore, both court and tribunal need to control the flexibility and appropriateness of the interpretation of clauses, so as to avoid the consequences that affect the authority of international law and judicial expansion.

\section{REFERENCES}

[1] Case Concerning the Detention of Three Ukrainian Vessels(Ukraine v. Russia Federation), Request for the prescription of provisional measures, ITLOS, Order of 25 May 2019, paragraph 32

[2] Case Concerning the Detention of Three Ukrainian Vessels(Ukraine v. Russia Federation), Request for the prescription of provisional measures, ITLOS, Order of 25 May 2019, paragraphs 101 and 102

[3] Strait to war? Russia and Ukraine clash in the Sea of Azov, European Council On Foreign Relations, Andrew Wilson, 2 October 2018, https://ecfr.eu/article/commentary_strait_to_war_ru ssia_and_ukraine_clash_in_the_sea_of_azov/

[4] Endre Szénási, The Kerch Strait Incident: Why the 2003 Treaty Regulating the Azov Sea Rights has not been Terminated by Russia (4 December 2018), P.3

[5] Case Concerning the Detention of Three Ukrainian Vessels(Ukraine v. Russia Federation), Request for the prescription of provisional measures, ITLOS, Order of 25 May 2019, paragraph 34

[6] Case Concerning the Detention of Three Ukrainian Vessels(Ukraine v. Russia Federation), Request for the prescription of provisional measures, ITLOS, Order of 25 May 2019, paragraph 106

[7] Case Concerning the Detention of Three Ukrainian Vessels(Ukraine v. Russia Federation), Request for the prescription of provisional measures, ITLOS, Order of 25 May 2019, paragraph 36, paragraph 37

[8] Case Concerning the Detention of Three Ukrainian Vessels(Ukraine v. Russia Federation), Request for the prescription of provisional measures, ITLOS, Order of 25 May 2019, paragraph 64

[9] Case Concerning the Detention of Three Ukrainian Vessels(Ukraine v. Russia Federation), Request for the prescription of provisional measures, ITLOS, Order of 25 May 2019, paragraph 68

[10] Case Concerning the Detention of Three Ukrainian Vessels(Ukraine v. Russia Federation), Request for the prescription of provisional measures, ITLOS, Order of 25 May 2019, paragraph 52
[11] Dissenting Opinion of Judge Kolodkin, paragraph 9

[12] Case Concerning the Detention of Three Ukrainian Vessels(Ukraine v. Russia Federation), Request for the prescription of provisional measures, ITLOS, Order of 25 May 2019, paragraph 64

[13] Dissenting Opinion of of Judge Kolodkin, paragraph 9

[14] Separate Opinion of Judge Gao, paragraph 33

[15] Keyuan Zou, Qiang Ye, Interpretation and Application of Article 298 of the Law of the Sea Convention in Recent Annex VII Arbitrations: An Appraisal, Vol.48, p.4

[16] Tom Ginsburg, International Judicial Lawmaking, p.12

[17] Separate Opinion of Judge Gao, paragraph 5

[18] Francesco Francioni, Peacetime use of Force, Military Activities, and the New Law of the Sea,Cornell International Law Journal, VOL.18,p.205

[19] Xinxiang Shi and Yen-Chiang Chang, Shi_Order of Provisional Measures in the Russia $v$ Ukraine case, 10, Vol.12, p.286

[20] Declaration of Judge KITTICHAISAREE, paragraph 4

[21] Declaration of Judge KITTICHAISAREE, paragraph 5

[22] Xinxiang Shi and Yen-Chiang Chang, Shi_Order of Provisional Measures in the Russia v Ukraine case, Vol.2, p.282

[23] Alexander Proelss, United Nations Convention on the Law of the Sea a commen- tary,P.190

[24] Case Concerning the Detention of Three Ukrainian Vessels(Ukraine v. Russia Fed- eration), Request for the prescription of provisional measures, ITLOS, Order of 25 May 2019, paragraph 65

[25] PCA Case No 2013-19, In the Matter of the South China Sea Arbitration, Award, 12 July 2016, paragraph 1012

[26] PCA Case No 2013-19, In the Matter of the South China Sea Arbitration, Award, 12 July 2016, paragraph 893

[27] PCA Case No 2013-19, In the Matter of the South China Sea Arbitration, Award, 12 July 2016, paragraph 893

[28] PCA Case No 2013-19, In the Matter of the South China Sea Arbitration, Award, 12 July 2016, paragraph 1158 
[29] Alan Boyle, Christine Chinkin, The Making of International Law, P.315

[30] Case Concerning the Detention of Three Ukrainian Vessels(Ukraine v. Russia Fed- eration), Request for the prescription of provisional measures, ITLOS, Order of 25 May 2019, paragraph 52

[31] Shigeru Oda, Dispute Settlement Prospects in the Law of the Sea,Vol.44,p.865

[32] Gilbert Guillaume, The Future of International Judicial Institutions, Vol.44, p.854

[33] Tullio Treves, Fragmentation of International Law: The Judicial Perspective, p.216

[34] Karin Oellers-Frabm, Multiplication of international courts and tribunals and con- flicting jurisdiction Problems and further solutions, p.74

[35] Gilbert Guillaume, The Future of International Judicial Institutions, Vol.44, 1995, p.862

[36] Anne Peters, The refinement of international law: From fragmentation to regime interaction and politicization, Vol.15, p.681 